\title{
I Wish: Multigenerational Regrets and Reflections on Teaching Children About Money
}

\author{
Ashley B. LeBaron \\ Brigham Young University - Provo \\ E. Jeffrey Hill \\ Brigham Young University - Provo \\ Christina M. Rosa \\ Brigham Young University - Provo \\ Travis J. Spencer \\ Brigham Young University - Provo \\ Loren D. Marks

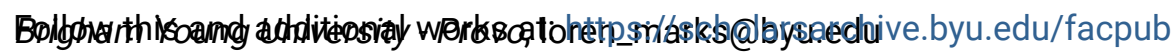 \\ Part of the Other Social and Behavioral Sciences Commons
}

See next page for additional authors

Original Publication Citation

*LeBaron, A. B., Hill, E. J., *Rosa, C. M., *Spencer, T. J., Marks, L.D., \& *Powell, J. T. (2017). I wish: Multi-generational reflections on parents teaching children about money. Journal of Family and Economic Issues.

\section{BYU ScholarsArchive Citation}

LeBaron, Ashley B.; Hill, E. Jeffrey; Rosa, Christina M.; Spencer, Travis J.; Marks, Loren D.; and Powell, Joshua T., "I Wish: Multigenerational Regrets and Reflections on Teaching Children About Money" (2017). Faculty Publications. 4853.

https://scholarsarchive.byu.edu/facpub/4853

This Peer-Reviewed Article is brought to you for free and open access by BYU ScholarsArchive. It has been accepted for inclusion in Faculty Publications by an authorized administrator of BYU ScholarsArchive. For more information, please contact ellen_amatangelo@byu.edu. 


\section{Authors}

Ashley B. LeBaron, E. Jeffrey Hill, Christina M. Rosa, Travis J. Spencer, Loren D. Marks, and Joshua T. Powell 


\title{
I Wish: Multigenerational Regrets and Reflections on Teaching Children About Money
}

\author{
Ashley B. LeBaron ${ }^{1}$ (i) - E. Jeffrey Hill ${ }^{1}$ Christina M. Rosa ${ }^{1} \cdot$ Travis J. Spencer $^{1}$ \\ Loren D. Marks ${ }^{1} \cdot$ Joshua T. Powell $^{1}$
}

Published online: 3 November 2017

(C) Springer Science+Business Media, LLC 2017

\begin{abstract}
Millennials are struggling to meet current financial challenges. As we strive to improve financial capability in future generations, it is important that we look to the primary source of financial education: parents. This qualitative, multigenerational study explored what Millennials and their parents and grandparents $(N=153)$ wish they had been taught about finances by their parents, as well as what parents and grandparents wish they had taught their children. Thematic content coding of the interviews revealed three core "I Wish" themes: "Practical Knowledge," "Financial Stewardship," and "Open Communication." These findings can assist researchers, family life educators, financial educators, parents, and future parents to enhance the financial education provided by parents in the home.
\end{abstract}

Keywords Financial socialization - Financial education . Parenting · Family finance $\cdot$ Millennials $\cdot$ Emerging adults · Qualitative

\section{Introduction}

We have a societal-level problem: Today's emerging adults (Millennials) are struggling with financial literacy (Lusardi et al. 2010). They are wrestling to acquire the necessary financial capabilities and are significantly delaying transitioning from financial dependence to financial independence (Xiao et al. 2014). Financial independence is an essential criterion for entering adulthood (Arnett 2000), and Millennials'

Ashley B. LeBaron

lebaronashley@gmail.com

1 Brigham Young University, 2086 JFSB, Provo, UT 84602, USA delay of adulthood has a potentially deleterious effect on the economy and on society as a whole.

The heart of this problem is that Millennials lack essential financial knowledge. Numerous studies have found that higher levels of financial knowledge are associated with more positive financial behaviors and financial well-being (Hilgert et al. 2003; Hira 2012; Huston 2012). In contrast, lack of financial knowledge is associated with many negative personal, family, and societal problems (Britt and Huston 2012; Dew 2007, 2011; Gudmunson et al. 2007; Hira 2012; Xiao et al. 2014).

The key to remedy this lack of financial knowledge is by providing financial education: the earlier in life, the better. Much of the current financial education research has been focused on financial education programs in public schools (Sherraden et al. 2011). As is evident by the financial struggle experienced by Millennials, however, these financial education programs are not solutions in and of themselves. Perhaps it is important to shift the primary financial education focus from academic-based programs and classes to what has been proven to be a more influential source: parents (Grinstein-Weiss et al. 2012; Jorgensen and Savla 2010). Studies have indicated that parental modeling and teaching has been associated with the most positive, impactful, and long-lasting financial attitudes and behaviors of emerging adults (Jorgensen and Savla 2010; Kim and Chatterjee 2013).

Financial education should be of particular importance to parents, mainly because they are often the ones who end up paying, literally, for the lack of financial capability and independence of their children. According to Settersten and Ray (2010), on average, families spend about $10 \%$ of their annual income supporting children between the ages of 18-21. Perhaps this burden could be reduced if emerging adults better understood financial management. Indeed, parents can play 
an irreplaceable role in helping their children to understand these concepts.

What do Millennials wish their parents had taught them about finances? The purpose of this paper is to begin to explore this question. Our study utilized a sample of $128 \mathrm{stu}-$ dents, 18 of their parents, and 7 of their grandparents. Participants were interviewed regarding their retrospective perceptions of what their parents taught them about finances, and, for parents and grandparents, what they taught their children about finances. Although the interviews were initially strengths-based, we began to notice that many respondents would express "I wish..." statements indicating what they wish their parents had taught them (or what they wish they had taught their children) but unfortunately did not. After noticing this interesting pattern, we began asking about regrets more purposefully in the interviews. Our intention in exploring this topic is certainly not to censure parents and highlight their shortcomings related to their financial education methods, but instead to inform them, researchers, and financial educators by bringing to light some of the reasons Millennials may lack financial capability and independence.

\section{Literature Review}

There is a growing concern regarding financial literacy and financial behavior among the rising generation (Babiarz and Robb 2014; Lusardi et al. 2010). Traditionally, there has seemed to be a learning curve regarding financial literacy for the young as they learn from financial mistakes and experience. However, financial difficulties and harmful practices seem to be increasing, particularly among emerging adults (Clarke et al. 2005; Jorgensen and Savla 2010; Lusardi et al. 2010). Financial competency test scores continue to decline (Jorgensen and Savla 2010), national student loan debt continues to increase (Reed and Cochrane 2012), and emerging adults are the fastest growing group of bankruptcy filers (US Congress Senate Committee on Banking, Housing, and Urban Affairs 2002).

A review of literature presents a strong case that parents have played a vital role in their children's financial capability (Chowa and Despard 2014; Clarke et al. 2005; Jorgensen and Savla 2010; Kim et al. 2011; Lusardi et al. 2010). Studies have shown that parents have a significant influence on their children's financial knowledge (Tang and Peter 2015), financial attitudes (Jorgensen and Savla 2010), and financial behaviors (Grinstein-Weiss et al. 2012, 2011). Serido and colleagues (2010) found that quality financial communication from parents not only led to higher financial well-being but was also associated with higher psychological and personal well-being. Emerging adults reported that they felt more prepared for financial responsibilities if they were modeled in the home (Clarke et al. 2005), however, one study showed that parents may believe that it was not their responsibility to teach finances to their children (Jorgensen and Savla 2010). The discrepancies found within the Millennial generation's financial capability may be largely mitigated for future generations through correct parental modeling and teaching, but parents need to first be educated on the responsibility they have to teach their children about finances as well as what financial principles to teach their children.

Social learning theory (Bandura and Walters 1963) provides some explanation for why parents play such a large role in their children's financial beliefs and behaviors. Children learn financial practices and attitudes by watching their parents use money and then imitating what they observe. This social learning approach is reflected in Gudmunson and Danes' (2011) family financial socialization model, which suggests that family processes influence financial behavior and wellbeing. Behavioristic approaches to learning theory would also add that children and emerging adults learn financial principles through experience, dealing with rewards and punishments for their personal financial decisions (Otto 2013). Sadly, without much financial modeling or overt financial teaching in the home (Clarke et al. 2005), many emerging adults are having to gain financial literacy the "hard way," i.e., through behaviorist means. Finally, cognitive developmental structuralist theory argues that developmental stages can be observed in a child's economic thinking (Otto 2013). This suggests that emerging adults may not be fully developed in their economic thinking, offering insight as to why they are struggling financially. These theories add valuable pieces to the puzzle of Millennials' economic behavior.

With the increasing gap between where Millennials' financial knowledge should be and where it actually is, many researchers have taken a vested interest in this particular issue. A small but important niche of researchers focus on financial education taking place within families. This is important because it explores what parents are actually modeling for and teaching their children. For example, LeBaron and colleagues (2016) described four main principles that are essential to financial education within families: the importance of financial vision, hard work, money management knowledge (i.e. budgeting, saving, avoiding debt), and generosity. Additionally, Clarke and colleagues (2005) described the important yet different roles mothers and fathers play in modeling financial principles for their children, such as the principles of budgeting and saving for mothers and financial tasks for fathers.

Other researchers have investigated in what specific areas of finance these Millennials seem to be lacking knowledge (Anderson and Card 2015; Brougham et al. 2011). This approach is instructive in that it helps financial educators get a better idea of where to focus curricula. For example, less 
than one-third of young adults have a basic understanding of interest rates, inflation, and risk diversification (Lusardi et al. 2010).

These research questions have shed light on the subject of financial education and the need for its further development. Our research approach is to go directly to the source, Millennials themselves, in order to gain a more complete picture of what they wish they knew financially. Additionally, we employ a multigenerational approach in order to gain greater clarity and understanding of these Millennials' experiences in their families. What and how do Millennials and their parents and grandparents wish they had been taught about finances from their parents? What and how do the parents and grandparents of Millennials wish they had taught their children about finances? We hope that these multigenerational insights will be helpful in enhancing financial education initiatives, particularly within families.

\section{Methods}

This paper is part of a larger study, the Whats and Hows of Family Financial \$ocialization project (LeBaron et al. 2016). The purpose of this multi-generational, qualitative project is to better understand what and how parents are teaching their children about finances.

\section{Sample}

The convenience sample for this study ( $N=153$ participants) included 128 undergraduate students (ages 18-30) enrolled in family finance classes at a private university in the Intermountain West, a public university in the Midwest, and a state university in the Southwest. Additionally, 18 parents and 7 grandparents of students were also interviewed, thereby providing reports and perspectives from three generations (college student, her/his parent, her/his grandparent). This resulted in a total of 7 student, parent, and grandparent triads, as well as 11 additional student and parent dyads. We felt this approach would be informative and valuable in addressing our research question, considering Handel's (1996) observation that "No [single] member of any family is a sufficient source of information for that family" (p. 346).

The sample was $63 \%$ female (97 of 153 ) and $37 \%$ male (56 of 153). The racial composition of the sample was $71 \%$ (108 of 153) White and 29\% (45 of 153) ethnic and/or racial minority (including African American, Asian, Latino/a, and Pacific Islander) individuals.

\section{Procedures}

Qualitative interviews were conducted by trained team members either face-to-face or over-the-phone. All interviews were conducted in a research office on a university's campus, with the majority of interviews lasting 15-30 min. Interview questions asked participants specifically what financial principles were taught by their parents and how those principles were taught. All interviews began with variations of two open-ended questions: (1) "What did your parents teach you about money?" and (2) "How did they teach you those things?" Follow-up questions were then asked to extract further information from the participant based on their responses. Parent and grandparent interviews generally ran slightly longer than the student interviews, usually lasting between 30 and $60 \mathrm{~min}$. In addition to the previous two questions, parent and grandparent interviews also focused on (1) "What did you teach your children about money?" and (2) "How did you teach those things?" Although the purpose of the interviews was initially to focus on beneficial principles and practices that were taught, the researchers began to notice that the participants were, without any prompting, making comments such as, "I wish my parents would have taught me more about _____.." Because of this obvious trend in the interview phase, we began asking participants what they wish their parents would have taught them, and, for parents and grandparents, what they wish they would have taught their children.

All 150 interviews (one interview was composed of a married student pair, another both parents, and a third both grandparents) were recorded and transcribed verbatim. The data were then coded as explained in the next section.

\section{Coding and Analyses}

In order to produce "more valid, reliable, and rigorous qualitative research" (Marks 2015, p. 494) we decided to use a team-based approach to qualitative data collection, analysis, and coding (for detailed explanation, see Marks 2015). The strategies which contributed to greater reliability include (a) developing a detailed audit trail for sampling, questionnaire usage, and qualitative coding that demonstrate and provide a "replicable method of inquiry" (p. 499); (b) building a qualitative research team that engages diverse team members; and (c) coding the data in coding pairs with a focus on inter-rater reliability that allows for multiple voices but "tempers the idiosyncrasies [and biases] of any single member" (p. 502).

The research team divided into five coding pairs to analyze the data. Both members of each pair independently open coded each interview and then met together to review (line-by-line) their open codes in a check and balance system, resolving discrepancies as they arose. Composite interrater reliability was exceptionally high, slightly over 0.90 , with discrepancies as incidents in which coding partners had varying independent coding and could not completely agree on a resolution. The coded excerpts were tracked using NVivo 11 qualitative software. In the team-based method we 
Table 1 Numeric content analysis

\begin{tabular}{lcccc}
\hline Theme & \# References & \# Sources & \% Interviews & $\begin{array}{l}\text { Average \# } \\
\text { Ref. per Int. }\end{array}$ \\
\hline Practical knowledge & 270 & 122 & 96.1 & 2.1 \\
Financial stewardship & 81 & 51 & 40.2 & 0.6 \\
Open communication & 117 & 70 & 55.1 & 0.9 \\
Total & 468 & 127 & 100 & 3.7 \\
\hline
\end{tabular}

Calculations were made based on the 127 interviews that mentioned "I wish," not the 153 total interviews conducted in the larger study employed, only emergent themes that were repeatedly identified and documented by all team members were "designated with the carefully reserved appellation of core theme" (Marks 2015, p. 503, emphasis in original).

Of the 153 people interviewed, 127 mentioned something they wish they had taught or been taught. As our team coded the interviews, we identified three (consensus) core themes relating to "I Wish" (Table 1). Those three core themes will be presented along with supportive and illustrative data in the Findings section, next.

\section{Findings}

The following three themes represent many of the "I wish..." expressions from the 150 interviews of Millennials and their parents and grandparents. The first theme (Practical Knowledge: "They never taught me how to budget") addresses financial information they reportedly wished they had taught or had been taught more thoroughly. Theme 2 (Financial Stewardship: "I didn't get tons of opportunities to budget my own money") addresses financial experiences, opportunities, and responsibilities many participants seemed to feel they had missed. The third and final theme (Open Communication: 'I've never seen my parents' budget or heard them talk about it") captures apparent reports of squandered opportunities to teach via parental modeling of wise financial behavior and meta-discussion. Although parents and grandparents referenced all three themes, references to the latter two themes were less common.

\section{Theme 1-Practical Knowledge: “They Never Taught Me How to Budget"}

The analyzed data from our participants repeatedly featured reports that many seemed to wish their parents had taught them more practical financial knowledge such as how to budget, how to file taxes, and how to wisely save and invest money. This first and most common theme was mentioned 270 times, an average of 2.1 references per interview. Further, this theme was found in 122 of the 127 "I wish" interviews $(96.1 \%)$. While many participants mentioned one or two topics that they wished they knew more about, some seemed to express deep frustration with their glaring lack of financial education, knowledge, and abilities. Nicole ${ }^{1}$ (White mother) said, "I don't remember my parents ever really specifically teaching anything [about money]." Kayli (White female Millennial) exclaimed,

...in this [family finance] class, I'm like, "What the heck! Why didn't I even know about this?"...I know this is stupid, but some of it I had no idea [about]. I was like, "I've never heard about this!"

When asked specifically about investing, Stephanie (White female Millennial) reported, "I didn't even know what [investing] meant until...a family finance class. [My parents] have invested my dad's whole career, and they know how to do it, but they never...passed that on to [me]."

Often, participants understood basic financial principles but had not reportedly received instruction on how to put them into practice. For example, Jessica (White female Millennial) explained, "[I wish I knew] the mechanics of how everything worked. [My parents] told [me] that everything was on autopay. But I wouldn't know how to pay a bill or to even set [autopay] up." Marisa (White female Millennial) said, "I felt like I understood basic financial principles, but there were other, more adult-like principles that I hadn't learned from my parents...I don't want to make unwise decisions."

This repeatedly referenced lack of financial knowledge often seemed to translate into a subsequent lack of financial confidence, as described by Hayley (White female Millennial).

Things like buying a house [and insurance] kind of freak me out, [and] I haven't really had to do taxes by myself yet. So that kind of stuff I don't feel very good at yet...I'm a little nervous right now.

Many participants seemed to express that they did not feel as confident in managing their finances as they could

\footnotetext{
1 All participant names have been replaced with pseudonyms in order to protect participant anonymity.
} 
have had they been taught more practical financial knowledge while they were young. For example, John (White male Millennial) said,

[My parents taught me] basic principles at a young age, and then as I got older they taught me a little bit more, but I still don't think they taught me a ton about more complex things like we're learning in [the family finance] class, more applicable stuff in life. I think I had to learn a lot of it on my own.

Multiple participants cited their parents' lack of practical knowledge as a probable reason they missed key aspects of a family-based financial education. Matt (White male Millennial) said, "I don't really know that [my parents] could've taught me any more based on what they knew. So I think to help me they could have put in the time and education [to learn more themselves]." Nate (White male Millennial) noted,

If my parents had the education they needed...they wouldn't have made poor financial decisions, and it wouldn't have affected our family as much as it did and put that stress on us. I think from my parents' perspective, they were scared to admit that they didn't know about finances. It was too overwhelming to even talk about the bills. [Healthy] finances bring power, they bring security, they help you provide for your family, [but] if you're stressed about finances, that can affect your family in a very negative way.

In addition to possessing financial content knowledge, Tyrone's (Black male Millennial) reported experience underscored the idea that in order for parents to adequately teach their children, they must first be present. Specifically, he lamented, "I learned later on that my dad is really good at financing but since he wasn't there, it kinda screwed me over." Participants seemed to believe that before parents can give their children adequate financial education, they must first be financially knowledgeable and capable themselves, and then be sufficiently present (both literally and educationally) for their knowledge to be transmitted and conveyed through both modeling and teaching.

One of the financial topics participants most frequently reported that they wished their parents had better taught them was budgeting. When asked whether she felt confident about her financial capability, Anna (Asian female Millennial) replied,

No, because I have never seen my parents budget, and they never taught me how to budget, so that was a huge problem. Learning how to live below my income and learning how to sacrifice some and save...it's hard.

Neal (White male Millennial) lamented that being taught the basics of "budgeting would have saved me a lot of time and money..." Elle (White female Millennial) explained her view:

I think that [budgeting] is honestly the root of all financial things because it helps you prevent from overspending and it's just good to keep track of everything you're doing...I think that [budgeting is] really important.

Some participants apparently felt that if their parents had taught them more about using a frugal budget to avoid debt, they would be in a different place financially. When discussing debt, Kurt (White father) said,

That's [a principle] I [was not taught by] my parents... When I went to college I was kind of like, "Oh, they're going to give me student loans? Awesome!"...but [my wife and I] look back and think, "We could probably have lived on half [of what we borrowed]."

Another repeatedly referenced principle on participants' "I wish" list was saving (and/or investing) money. Kurt (White father) said of retirement savings,

[I wish my parents had taught me to] save early. I never really had a savings account until my working professional years [when] I [discovered that] if you start saving for your retirement when you are 22 as opposed to when you are 40 , the difference of the amount of money you would have saved up [is] huge! It's massive!... [That's the one thing] I wish I was taught when I was younger...It's a lot easier if you start that process young.

Similarly, when asked what he wished his parents had taught him, Charlie (White male Millennial) explained,

Saving. That was one [thing] I never even did with my money. I always just spent it frivolously, except for when I needed something, [in which case] I would save up...But those were just minor occurrences, rather than getting a long-term $10 \%$ of [my] money saved every single month. So I wish they would have emphasized that. I wish they would have emphasized the ins and outs [of consistent saving]...

Along with saving, participants often mentioned gaps in practical knowledge regarding investing. Lance (White male Millennial) lamented, "I didn't learn about the time value of money until I got to college. It hurts a little bit to think that if I was able to save all [my growing up] years that it could have been compounding." Zoey (White female Millennial) described her concern: "I am really nervous... because I know I want to invest, but I have no idea where to start." Additionally, many parents and grandparents expressed regret that they did not teach their children this financial knowledge. Victoria (White mother) seemed to 
recognize her weakness in teaching about investing as well as the multigenerational nature of financial education when she admitted,

One thing that [my husband and I] haven't done [is teach our children] about investing and stocks. Our work [invests] for us...I wish I knew more about that to teach our kids to invest...I should know more about that [so I can] help them... [Our parents] didn't [teach] us [about investing either].

Kurt (White father) shared a similar account of his apparent deficit in teaching his children about investing that highlights how parents' financial education efforts (or lack thereof) can be similar across generations:

On the investing side, [our children] know that Mom and Dad are saving for retirement, but we have not talked to them about, "You know, as soon as you can get $\$ 1,000$ saved, put it in an IRA. Add a little bit here or there, start when you're 21." We haven't done that... So in that part we have been lacking... Because my parents never went to college, retirement savings was never really in [their] plan. But now it is for us...

Although many discussed wishing they had taught or been taught more regarding saving and investing, some participants wished that their parents had taught them or that they had taught their children to spend more. For example, Gus (White grandfather) reflected,

[My parents] should've taught me to loosen up a little bit. I was pretty tight. I didn't wanna throw money around, and I was pretty pinchy. I didn't treat my wife with enough dresses...my focus was to not spend too much money. So maybe I was too much of a saver.

Audrey (White female Millennial) expressed a similar sentiment and then explained this reasoning:

It's a bad thing to be an extreme saver because then you miss out on the enjoyment you could have in life. The purpose of money is to pay for your needs but also to do good things with it... You can set aside money for fun things and not feel guilty.

Lily (Asian female Millennial) described a reportedly unnecessary fear she developed regarding finances:

I remember I had this fear of credit cards and investments because my grandparents had investments in a condo and it went [bad]. And so I just heard that story and then when I came into the finance class I was like, "Investments are good?! Credit cards [can be] OK?!" So I learned to save, but I didn't know how to use [money] well. So I'd just keep it in my savings account and think, "OK, just stay there. It'll be OK."
Perhaps some of the fears expressed by participants could have been overcome or at least ameliorated had their parents given them financial stewardship, as described in the next theme.

\section{Theme 2-Financial Stewardship: "I Didn't Get Tons of Opportunities to Budget My Own Money"}

The second recurring theme in the interview data was that participants wished they had given, and been given, more financial stewardship or responsibility. This theme was mentioned 81 times, an average of 0.6 references per interview. While less prevalent, some parents and grandparents correspondingly reported that they wish they had given more financial responsibility to their children during the formative years.

Specifically, participants reportedly wished they had been given chances to work for their own money, get a job, and save for their own purchases. They wished their parents had entrusted them with greater responsibility and flexibility regarding financial decisions early on so that they would be more comfortable and confident in making those decisions as emerging adults. For example, Colton (White male Millennial) expressed,

[My parents] set up [a bank] account for me...but I didn't quite know what was mine or what my responsibilities were exactly. So when I was making that transition from dependence to independence financially, it would've been nice to be the one [who had taken] the initiative...[I wish] they would have taught me how to establish my account or let me have the opportunity to do it by myself so I was fully responsible.

Many participants seemed to express that the financial knowledge their parents taught them was not effective in instilling financial capability because they were not given opportunity to apply what they learned first-hand. Henry (White male Millennial) said,

I struggled [for] a long time with really basic things such as the difference between debit and credit...I feel like it's partly because [my parents] didn't teach [me]. Well, they tried to, but I'd just forget the things [they taught] because I didn't have a debit or credit card, so [I couldn't] actually start applying it.

Similarly, Erika (White female Millennial) said,

I remember my parents sitting down with us and going through their budget. So we learned how much my dad makes in a month, how much they put their money towards everything, and that was a big eye opener for me. I realized how much things cost and how expensive everything is and that it's good to 
budget so you know how much money is going different places. But I didn't get tons of opportunities to budget my own money. [My parents] didn't really help me do that...I wish they did because I wish I had saved more than I did.

She continued, "I wish that [my parents] had given me more opportunities to spend money. They told [my siblings and me] how they spent their money, but they didn't really help us learn...how to spend [ours]." While it may be important for parents to teach children about finances and share their own financial experiences, if children are not given opportunities to manage their own finances, they may not internalize the principles and enact the practices taught.

According to participant reports, a key part of learning to manage finances effectively involved opportunities to contribute money toward an item or event. Pete (White male Millennial) remembered,

I never had to pay for gas or car insurance, and maybe [it] would have been beneficial for [my parents] to have allowed me to....at least contribut[e] to something. Of course I had to get good grades to have the privileges, but it would have been nice to have them help me contribute because I feel like as you learn to manage money [when you're] younger, you'll make less mistakes when you're older. I think that would have been helpful for me.

While we may presume that this Millennial's parents had good intentions in paying for all of his driving expenses, perhaps employing a system that required him to pay part of the expenses would have helped him learn crucial money management skills. Charlie (White male Millennial) expressed his thoughts about children contributing financially as follows: "My parents just paid for [everything] — my [church] mission, all the weddings in the family,...I wonder if [these events] would have meant more to me [had I] learn[ed] the process of saving that kind of money." Lucia (Hispanic female Millennial) also connected personal financial contribution to valuing an item or event:

[My parents] could have [encouraged my siblings and me to pay] for things...ourselves so we could feel more responsible about the things we had. We would value it more. Instead of them giving us a lot of things because they feel like..."I never had this, so I want to give you this"...I [wish they had held] off a little bit and [encouraged us to] raise half [the money ourselves].

In addition to paying for items or events, participants reportedly wished that their parents had given them firsthand experience with debt and loans while they were young. Stephanie (White female Millennial) said,
When I was 15 , I started a lawn aeration business...I went to start [the] business, my parents paid for the machine, and I paid them back. But, I would so much rather have had them help me take a loan out from an established bank or whatever and then pay it off myself so that I could learn the real process... it would have helped me to venture out on my own.

As this Millennial proposed, perhaps teaching children how borrowed money works by providing them with realworld experiences may help foster financial independence.

Amber (White female Millennial) told how she was not held accountable for debt:

...one thing [my parents] did not teach [my siblings and me] very well [was to pay] people back. In high school I had a car and didn't have to pay for it except for gas, which is like a free car. I was a bad driver and crashed it a few times. This has happened with all my siblings, and we were supposed to pay [my parents] back for the repairs or increase in premiums. But they never really followed through on that, and I know that we haven't paid my parents back for all the accidents...I think it is really important to [hold your children accountable and to teach them to] pay people back when you borrow something from them.

Some participants, such as Stephanie (White female Millennial), also mentioned that they wished their parents had given them the opportunity to financially invest while they were still young:

I wish [my parents] would have taught [my siblings and me] about investing and had us start investing at an early age...I think starting at even eight or nine years old would be good. Then [we] could learn that terminology starting young. I think the amount of knowledge and growth that you could learn in that decade [from eight to eighteen] would be really great and put you ahead in life.

Other participants seemed to express regret that their parents did not encourage them to work harder or get a job. Amber (White female Millennial) reflected, "I would just ask my parents for money, and they would give it to me without [making me work]. I don't think that was a good thing. I felt spoiled." The interviewer then asked if Amber hoped to do it differently if she became a parent, to which she replied, "Yes. If [my children] want money, I will say, 'Oh, go clean my car' or something." Erika (White female Millennial) similarly stated, "I think it may have been good to have [me work more]...I think it's lucky that [I'm] not lazy."

While some participants discussed the lack of a homeinstilled work ethic, other participants reportedly wished 
they had more experience with outside-the-home employment as well. Hayley (White female Millennial) described the source of her apparent anxiety about her financial future:

[I was] never allowed to have a job growing up, and I always wanted a job...[My parents] never [let me work] because...we always just had what we needed... [They continued to support me through college but] they're not going to be supporting me once I leave college, which is pretty soon. I kind of feel scared about that...I don't feel fully prepared...I was [always] just given everything...I'm really nervous about that.

Jed (Asian male Millennial) summarized, "I wish [my parents had] taught me a little more [about]...what I could have done with the money...I wish my parents [had told] me [that] the choice [was] up to me..." While a hunger for additional responsibility seemed to be frequently expressed, a few participants reportedly wished they had given or been given stricter guidelines for managing finances. For example, Janice (White mother) said,

I wish I had [laid] down more guidelines when I gave [my daughter a] credit card...I was shocked that she went out and spent $\$ 500$ buying shoes. So I learned with the next one, when I gave him another credit card; he only had a $\$ 500$ balance maximum on it... [I had been] adding them to my account, so she could have done a lot [of] damage...

Similarly, Naomi (Black female Millennial) expressed,

I wish that I would have learned to be more [financially] responsible younger, like when I was...living at home with [my mom]. [I wish she had] not giv[en] me exactly what I wanted all the time because now it's hard.

Most participants seemed to feel that children should be given age-appropriate responsibility. And, overall, most participants reportedly wished they had been given more financial responsibility, stewardship, and opportunities for firsthand contribution and employment when they were children.

Catherine (White female Millennial) explained, "I think that [practice using money] gives kids confidence to make their own financial decisions." Perhaps children will handle financial responsibility better if their parents more transparently share how they handle their own finances, an idea explored in the third and final theme, next.

\section{Theme 3-Open Communication: "I've Never Seen My Parents' Budget or Heard Them Talk About It"}

The third and final theme we found captures participants' wishes that their parents had more openly communicated with them about the family's finances. This theme was mentioned 117 times, an average of 0.9 references per interview. Charlie (White male Millennial) said, "I wish [my parents] would have [been]...more open about the family finances because it was always just a big mystery." By contrast, parents and grandparents rarely mentioned that they wished they had been more open with their children-this "wish" was dominated by Millennials mentioning what they wish they had received. Millennials reportedly wished their parents had facilitated sit-down lessons or family councils to discuss the family's finances. They wished their parents had shared with them their budget, income vs. expenditures, retirement plan, debt, investments, etc. For example, Audrey (White female Millennial) said, "I wish I would have known more about how [my parents] pay taxes or [pay] the bills or how our family's finances were going - or even [our] debts and how we'd pay th[em]." Participants seemed to wish that finances had been more of an ongoing, open conversation over the years. They apparently felt that they could have been better prepared for their own financial futures had they learned about their parents' finances. Kylie (White female Millennial) expressed her feelings:

Even though in this day and age...[we can] go Google something, I think that...especially for [a topic so] important and personal...it's good for...parents to talk with [their child] about [finances] because. .. their personal experiences can be helpful for their child.

One aspect that participants wished their parents had been more open about was family income. Ryan (White male Millennial) recalled, “I didn't know what [my parents'] salary was or how much was in their savings account...I kind of wish I knew more about that...I really have no clue about it." Charlie (White male Millennial) remembered,

[My parents] wouldn't even tell me how much my dad made...I would ask when I was little... and they wouldn't tell me until I was like 17 or 18 ...It was very closed book...My dad's a software engineer so I just googled [the] average salary of a software engineer. I'm like, "Dad, do you make this much money?" and he's like, "Yes, I do."...If I ever asked, "How much do we owe on the house?" it was all hush hush...

Some participants seemed to express that a lack of knowledge about their family's finances caused them unnecessary stress and concern. For example, Vienna (White female Millennial) said,

I remember [my family] would go to Costco, and I would see so many things in the cart and think, "Where does this money come from?" not understanding that someone's working for this, [that] that's why Dad goes to work. He gets that money, and there's enough... [It] would have been... helpful to understand the whole 
making-and-spending process. It would have helped me in my anxiety.

Amy (White female Millennial) offered her thoughts for parents who, for one reason or another, do not wish to divulge to their children exactly how much they make:

It's...important to not feel uncomfortable [when talking to your children about the family's finances]. I know that my dad sometimes feels uncomfortable when we ask about his finances. He says, "I don't want to tell you how much I make." He's pretty private about that. That's fine. But, I think there are ways that you can open up and be more open to having those conversations without saying things that make you feel uncomfortable. Like, if your kid asks about how much the house costs, then you don't necessarily have to explain, "Our house is this much," but you could still explain what a mortgage is and that kind of thing.

Many Millennial participants wished their parents had told them how much they make, at least approximately. Based on the interviews, perhaps open communication about family income can prevent unnecessary stress and act as a teaching tool.

Participants also expressed regret that their parents had not been more open with them about the family budget. Sara (White female Millennial) said,

I never knew how [my parents] made a budget for themselves. I think that would have been interesting as a child to see, "Oh, my parents spend this much on food" or whatever. I know they kept a budget...it would have been interesting to see that...

Some participants seemed to feel that candor regarding the family's finances could have served as a helpful example to go hand-in-hand with financial knowledge taught. Jessica (White female Millennial) remembered, "I think [my parents] have a budget, [but] I was never involved in that process. We talked about budgeting but not really in specific terms. They just advised us to use a budget." Heather (White female Millennial) said, "In high school...I wanted to know ...how much to put towards each category of a budget. I wish [my parents] would've taught me those things and how they decided what goes to what." Several of those interviewed seemed to describe how their parents' lack of open communication regarding budgeting has negatively impacted their own financial capability and independence. Jacob (White male Millennial) stated,

I...want to emphasize [that family finance] really wasn't a common topic in [our] home. It was almost taboo... and really wasn't discussed with the kids much...I am having to learn a lot of things on my own, which has cost me financially...I've never even seen my parents' budget or heard them talk about it, so that's completely foreign to me.

While Millennial participants acknowledged that their parents may have withheld financial information from them because the family's financial situation was less than ideal, participants apparently wished that their parents had involved them in getting through these hard times together. For example, Matt (White male Millennial) recalled,

[My parents] didn't talk about [finances] very much, which I think could have been one of the problems. I just knew that there was a large amount of debt...So as far as my actual involvement in the family finances, it was very little.

Similarly, Maria (Hispanic female Millennial) expressed,

I wish that [my parents had]...talked to me a little bit more about [their financial situation]...I feel like [they] kind of hid it. I knew we were struggling... so I wish they would've communicated to me what was going on...because I felt like I was kind of thrown at the wolves....I think I would've been more understanding of it all if they had talked to me about it.

Participants seemed to believe that they could have helped their parents and that greater involvement could have had a positive impact on their own financial capability and independence later on. Tia (Black female Millennial) shared,

[My mom] kept us in the dark because she didn't want us to know that we didn't have enough... She wanted it to be hidden so we didn't have to worry about [things, but] I wish she would have explained because then I could have helped more... [And] knowing what my parents went through would have prepared me for the do's and don't's of finances.

In conjunction with budgeting, several participants also mentioned that they wished their parents had included them in the processes of setting and reaching family financial goals. When asked how open her parents had been with her regarding the family's finances, Stephanie (White female Millennial) responded,

[They told me] almost nothing. They were pretty closed-doored about it. There were no sit-down meetings about family budgeting or the money it costs to go on a vacation. It would have been nice to have a family goal to pitch into, [like to] save up for a family vacation so that the vacation felt more rewarding for us. That would have made us appreciate it as much as our parents did...Kids don't need to know everything, but they at least need to know what is going on and at least have a common goal between parents and children that can help achieve something... 
Amber (White female Millennial) said,

[My parents] never told us kids about their financial state. They were just more private about it. They just wanted us to be kids and not worry about it. I wish they would have [told us more] because that would have given me insight for the future. [I wish they had been] more open, like say, "Listen, here is where we are at. Here is our goal. Here is what we have to spend and what we want to save for."

Other reasons participants gave for why sharing the family budget may be helpful in teaching children about money included that doing so can be a good model for children's own budget and this modeling can provide children with realistic expectations of what their finances may be like when they are adults. For example, Camila (Hispanic female Millennial) said,

[I wish my parents had] sat down and...laid it all out and budgeted and did that net worth thing. I think that would have been really helpful and prepared us for the future we would have to face-reality.

Harry (White male Millennial) reasoned,

It probably would have been good to... see what [my parents'] budget looked like or see what their actual expenses were so I could recognize how much money they brought in [and] also how much their expenses were so I had more realistic expectations. So for me... prom is like fifty bucks...Things I did in high school were my expectation of what things cost. I didn't... have a real grasp on...the difference between a $\$ 30,000$ job...versus a $\$ 60,000$ job and what that buys for a family. I [wish they had shown me], "OK, you have a family of six. This is how your expenses are when you're trying to take care of that many people."

Lexi (White female Millennial) similarly expressed frustration at having missed out on this glimpse of financial reality:

Now I see [that my parents] probably made [their financial situation] look better than it was...[so as] to not worry the kids... When you get in the real world, it's not that easy... When I got [to college], I saw reality. They should not [have painted such an] easy life.

Millennial participants also highlighted other aspects of finances that they apparently wished their parents had been more open with them about, such as bills and expenses, saving, investing, and debt management. Many seemed to feel that lack of open communication bred an uncomfortable environment and feelings of stress, concern, and a lack of trust. Emma (White female Millennial) said, "If [my parents] were trying to keep [finances] hidden and [not] talk about it, then I didn't feel as comfortable asking [them] about it because I didn't want to do something wrong." Based on reports, perhaps open communication about the family's finances can foster an environment of financial instruction while also better preparing children for financial capability and independence in emerging adulthood. Focusing on regrets is an unusual research approach-but the novelty of this approach also holds promise for a unique contribution to financial education and planning: a focus on early preventative and multi-generational efforts.

\section{Discussion}

The three principles presented here-teaching children more practical knowledge, giving them more financial stewardship or responsibility, and communicating more openly about finances with them-are the three main categories for what Millennials, parents, and grandparents wished their parents had taught them about finances, as well as what parents and grandparents wished they had taught their children (Table 1). These findings speak powerfully to how a lack of financial teaching in the home may be a contributing factor in the current financial challenges being faced by today's emerging adults. Critical consideration of these wishes gives insight into current parental challenges regarding financial teaching as well as directions for family life educators and future research.

Practical knowledge was overall the most desired thing that participants wished that their parents had taught them. They wished they had been taught how to budget, to invest, and other "what's" and "how's" key to financial adulthood. Participants expressed that if they had been given more knowledge as children, they would be making fewer mistakes and be more financially stable as emerging adults and adults. A few barriers were proposed for parents teaching children practical financial knowledge. One was that parents might think that their children would not understand the concepts, even if they did try to teach them. Additionally, parents might not understand correct financial principles and practices themselves, which would inhibit their ability to teach them to their children. Parents might also excuse themselves from teaching practical knowledge because they think that their children will be taught sufficient information in school or elsewhere. Parents may also be too infrequent in their teaching for children to really grasp an understanding of finances. Comparative to the infamous, uncomfortable "sex talk," parents may have the one-and-done mentality towards teaching their kids about finances. Just one talk rather than ongoing application may not allow the knowledge to sink in and stick. In order for children to recall financial 
knowledge when they need it-during their emerging adult years - they may require more regular, applicable conversations initiated by their parents throughout the years.

Participants also wished that their parents had given them more opportunities for financial stewardship. Valuable financial lessons can be learned through making financial mistakes. By giving children opportunities to manage finances early on, children can learn these lessons with minimal risk. Relatively, a 10 year-old makes $\$ 50$ mistakes, a 20 year-old makes $\$ 5000$ mistakes, and a 30 year-old makes $\$ 50,000$ mistakes. Therefore, allowing children the freedom to make and learn from financial mistakes at a young age protects them from making mistakes later on that could have more severe repercussions. Emerging adults who were not given those opportunities earlier on are recognizing this and reaping the consequences. Financial responsibility may prepare children for financial capability and independence in emerging adulthood. Reasoning for why children are not being given this desired stewardship could include that parents do not often consider their children's immense future financial responsibilities, or that parents may simply not trust their children with their money. Anecdotal data supported the idea that parents of Millennials often put a higher stress on children doing well in school rather than giving them opportunities to work and be stewards over money. However, these may not need to be mutually exclusive emphases. This lack of financial stewardship could be perpetuating Millennial entitlement issues and misconceptions of healthy financial practices.

Open communication about the family's finances was also strongly desired by participants as a way for parents to teach children finances more effectively. Open communication provides a way for children to learn both good and bad examples of how to use money in a safe environment from parents they trust. This vulnerability may help children learn from their parents' mistakes rather than having to make those same mistakes themselves. However, being open about personal finances, even with children, seems to be a taboo topic. In the same way parents avoid the "sex talk" with their children, parents also seem to avoid the "money talk." This discomfort may derive from parents' own financial ineptitude and could partially explain why so many parents do not share much with their children about their finances. Additionally, parents may be wary of their children talking to others about the family financial situation, or parents may not want their children to worry themselves about financial challenges the parents are facing. If parents can overcome these barriers for open communication, there could possibly be less financial illiteracy and more understanding of financial reality in the rising generation.

\section{Limitations}

We recognize that there are limitations to our study. Our themes may have arisen in the interviews simply because the students we interviewed had difficulty accurately remembering what their parents actually taught them because it was not then applicable to them. However, this limitation implies that parents need to be instructed in more effective ways to teach children financial principles and practices so that children will remember and be able to apply what is taught. Parents may also need more financial education themselves.

Another limitation is that our sample is primarily made up of college students enrolled in a family finance class. It is uncertain how much our findings can be generalized to all Millennials. Additionally, our sample of parents and grandparents was relatively small and findings may not be generalizable to all parents and grandparents of Millennials.

Though we do not claim full theoretical saturation for all of the themes reported by the students, we believe we are close. Indeed, we included student participants from three diverse universities to see if the themes would "hold" in a variety of environments. We found that the same themes emerged at all three locations. This is evidence of at least a moderate level of saturation among student participants. However, given our much smaller sample of parents and grandparents, it would be premature to make the same claim of saturation for them. Indeed, we think there is more to learn from them and encourage future research to include a larger parent/grandparent sample.

\section{Implications}

In addition to the obvious implications for parents themselves, the three themes that emerged from this study can assist family life educators, particularly financial educators, in developing outreach programs and financial education curricula concerning parental financial education. Educators should not only advise parents on what and how to teach their children regarding finances; parents should also be encouraged to teach and talk about finances more frequently. If educators can help parents effectively and frequently teach and model financial principles, children may be better able to remember and apply the principles and practices they are taught. If parental financial education were to be improved, these "I wish" statements could turn into "I'm so glad" statements.

These themes might also be useful for financial planners and financial therapists as they assist clients who may be struggling financially. For example, clients may lack sufficient financial knowledge and experience. Clinicians could benefit from an awareness of the financial socialization 
process and the frustrations clients may feel due to educational deficits.

This qualitative research also suggests many possible avenues for quantitative inquiry. Future research is needed to identify which specific aspects of finances are not being sufficiently taught by parents and what financial outcomes those deficiencies are linked with in emerging adulthood. Longitudinal studies that measure varying financial education during childhood and track financial outcomes as children grow would assist in the pursuit for optimal parental financial education. It would be interesting to test whether financial education taking place within families varies by SES or gender. Furthermore, it would be beneficial to explore how the three shortcomings examined in this study could be corrected. More diverse sampling would also improve the generalizability of the assertions we make throughout this paper.

\section{Conclusion}

This paper begins to address a societal-level problem by bringing to light some of the reasons Millennials may lack financial capability and independence (i.e., lack of financial knowledge, financial stewardship, and open financial communication). We hope that parents might use these findings to be better financial educators to their children so that future generations will be better prepared for financial adulthood. Additionally, we hope that educators will assist parents in this effort. Every effort invested into the financial competence and independence of the rising generation will reap significant economic and communal rewards that will help to secure our financial future. We believe these efforts must start in families, where the greatest financial influence occurs. One final caveat: The purpose of this paper is not to condemn parents of today's emerging adults, but to help them. They have done their best. As Olivia (White female Millennial) said, "I hope to be half of the parents my parents are."

\section{Compliance with Ethical Standards}

Conflict of interest The authors declare that they have no conflict of interests.

Ethical Approval IRB approval for the research project was secured in February 2015.

Informed Consent All participants signed a consent form prior to participation.

\section{References}

Anderson, C., \& Card, K. (2015). Effective practices of financial education for college students. College Student Journal, 49(2), 271-279.

Arnett, J. J. (2000). Emerging adulthood: A theory of development from the late teens through the twenties. American Psychologist, 55, 469-480. doi:10.1037//0003-066X.55.5.469.

Babiarz, P., \& Robb, C. A. (2014). Financial literacy and emergency saving. Journal of Family and Economic Issues, 35(1), 40-50. doi:10.1007/s10834-013-9369-9.

Bandura, A., \& Walters, R. (1963). Social learning and personality development. New York: Holt, Rinehart, and Winston.

Britt, S. L., \& Huston, S. J. (2012). The role of money arguments in marriage. Journal of Family and Economic Issues, 33, 464-476. doi:10.1007/s10834-012-9304-5.

Brougham, R. R., Jacobs-Lawson, J. M., Hershey, D. A., \& Trujillo, K. M. (2011). Who pays your debt? An important question for understanding compulsive buying among American college students. International Journal of Consumer Studies, 35(1), 79-85. doi:10.1111/j.1470-6431.2010.00923.x.

Chowa, G. N., \& Despard, M. R. (2014). The influence of parental financial socialization on youth's financial behavior: Evidence from Ghana. Journal of Family and Economic Issues, 35(3), 376-389. doi:10.1007/s10834-013-9377-9.

Clarke, M., Heaton, M., Israelsen, C., \& Eggett, D. (2005). The acquisition of family financial roles and responsibilities. Family \& Consumer Sciences Research Journal, 33, 321-340. doi:10.1177/10 77727 X04274117.

Dew, J. (2007). Two sides of the same coin? The differing roles of assets and consumer debt in marriage. Journal of Family and Economic Issues, 28, 89-104. doi:10.1007/s10834-006-9051-6.

Dew, J. (2011). The association between consumer debt and the likelihood of divorce. Journal of Family and Economic Issues, 32(4), 554-565. doi:10.1007/s10834-011-9274-z.

Grinstein-Weiss, M., Spader, J., Yeo, Y., Key, C., \& Freeze, E. (2012). Loan performance among low-income households: Does prior parental teaching of money management matter? Social Work Research, 36(4), 257-270. doi:10.1093/swr/svs016.

Grinstein-Weiss, M., Spader, J., Yeo, Y. H., Taylor, A., \& Freeze, E. B. (2011). Parental transfer of financial knowledge and later credit outcomes among low- and moderate-income homeowners. Children and Youth Services Review, 33(1), 78-85. doi:10.1016/j. childyouth.2010.08.015.

Gudmunson, C., Beutler, I., Israelsen, C., McCoy, J. K., \& Hill, E. J. (2007). Linking financial strain to marital instability: Examining the roles of emotional distress and marital interaction. Journal of Family and Economic Issues, 28(3), 357-376. doi:10.1007/ s10834-007-9074-7.

Gudmunson, C. G., \& Danes, S. M. (2011). Family financial socialization: Theory and critical review. Journal of Family and Economic Issues, 32(4), 644-667. doi:10.1007/s10834-011-9275-y.

Handel, G. (1996). Family worlds and qualitative family research: Emergence and prospects of whole-family methodology. Marriage and Family Review, 24, 335-348. doi:10.1300/J002v24n03_06.

Hilgert, M. A., Hogarth, J. M., \& Beverly, S. G. (2003). Household financial management: The connection between knowledge and behavior. Federal Reserve Bulletin, 89, 309-322.

Hira, T. K. (2012). Promoting sustainable financial behaviour: Implications for education and research. International Journal of Consumer Studies, 36, 502-507. doi:10.1111/j.1470-6431.2012.01115.x.

Huston, S. J. (2012). Financial literacy and the cost of borrowing. International Journal of Consumer Studies, 36, 566-572. doi:10.1111/j.1470-6431.2012.01122.x. 
Jorgensen, B., \& Savla, J. (2010). Financial literacy of young adults. Family Relations, 59(4), 465-478. doi:10.1111/j.1741-3729.2010.00616.x.

Kim, J., \& Chatterjee, S. (2013). Childhood financial socialization and young adults' financial management. Journal of Financial Counseling and Planning, 24, 61-79.

Kim, J., LaTaillade, J., \& Kim, H. (2011). Family processes and adolescents' financial behaviors. Journal of Family and Economic Issues, 32, 668-679. doi:10.1007/s10834-011-9270-3.

LeBaron, A. B., Hill, E. J., Rosa, C. M., Schmutz, C., \& Spencer, T. J. (2016). Teaching finances in the home. In Paper presented at the annual conference of the work and family researchers network, Washington, DC.

Lusardi, A., Mitchell, O. S., \& Curto, V. (2010). Financial literacy among the young. Journal of Consumer Affairs, 44(2), 358-380. doi:10.1111/j.1745-6606.2010.01173.x.

Marks, L. (2015). A pragmatic, step-by-step guide for qualitative methods: Capturing the disaster and long term recovery stories of Katrina and Rita. Current Psychology, 34, 494-505. doi:10.1007/ s12144-015-9342-x.

Otto, A. (2013). Saving in childhood and adolescence: Insights from developmental psychology. Economics of Education Review, 33, 8-18. doi:10.1016/j.econedurev.2012.09.005.

Reed, M., \& Cochrane, D. (2012). Student debt and the class of 2011. Project on student debt. Retrieved from http://eric. ed.gov/?id=ED537338.

Serido, J., Shim, S., Mishra, A., \& Tang, C. (2010). Financial parenting, financial coping behaviors, and wellbeing of emerging adults. Family Relations, 59, 453-464. doi:10.1111/j.1741-3729.2010.00615.x.

Settersten, R. A. Jr., \& Ray, B. (2010). What's going on with young people today? The long and twisting path to adulthood. The Future of Children, 20, 19-41. doi:10.1111/j.1741-3729.2010.00615.x.

Sherraden, M. S., Johnson, L., Guo, B., \& Elliott, W. (2011). Financial capability in children: Effects of participation in schoolbased financial education and savings program. Journal of Family and Economic Issues, 32(3), 385-399. doi:10.1007/ s10834-010-9220-5.

Tang, N., \& Peter, P. (2015). Financial knowledge acquisition among the young: The role of financial education, financial experience, and parents' financial experience. Financial Services Review, 24(2), 119-137.

US Congress Senate Committee on Banking, Housing, and Urban Affairs. (2002). The state of financial literacy and education in America. In 107th congress, senate hearing, pp. 107-969.

Xiao, J. J., Chatterjee, S., \& Kim, J. (2014). Factors associated with financial independence of young adults. International Journal of Consumer Studies, 38, 394-403. doi:10.1111/ijcs.12106.
Ashley B. LeBaron is a graduate student and lead research assistant in the Marriage, Family, and Human Development program at Brigham Young University. Her research focuses on family finance, specifically couple finance and financial socialization. Ashley was valedictorian for the College of Family, Home, and Social Sciences graduating class of 2016 at BYU.

E. Jeffrey Hill PhD, is Camilla Eyring Kimball Professor of Family Life at Brigham Young University. His research examines the influence of family finances on marriage and family relationships, as well as finding harmony between paid work and family life. Dr. Hill obtained a doctorate in Family and Human Development at Utah State University and Masters of Organizational Behavior from the Marriott School of Management at Brigham Young University. Before coming to BYU he was a work and family subject matter expert at IBM. Dr. Hill has published seven books and more than 90 scholarly articles and book chapters.

Christina M. Rosa is a graduate student and research assistant in the Marriage and Family Therapy program at Brigham Young University. Her research is focused on identifying best practices for parents teaching children about finances.

Travis J. Spencer is a graduate student in the Marriage and Family Therapy program at Utah State University. His research interests include relationship processes, addiction recovery, and family finance. Travis graduated from Brigham Young University's School of Family Life in December 2016 as an NCFR Honor Student.

Loren D. Marks is a professor in Brigham Young University's School of Family Life. His research interests have included religion and families, minority families, and family finance. He has authored 100 scholarly works including two books, Sacred Matters (with Wes Burr and the late Randy Day) and Religion and Families (with David Dollahite). His research on families has received national media attention from outlets including The New York Times, The Washington Times, The Boston Globe, and The Wall Street Journal. During his 13 years at LSU, he was twice nominated (in 2011 and 2014) by LSU for a national Carnegie (CASE) Professor of the Year Award. He is Co-Director (with Dr. David Dollahite) of the American Families of Faith Project.

Joshua T. Powell graduated with an Associates of Science Degree from Salt Lake Community College at the age of 17. He is currently a senior studying Applied Statistics and Analytics at Brigham Young University. 